\title{
The Upper Miocene fish fauna of the Fortuna Basin, as observed in the surroundings of Abanilla (Murcia province, Spain)
}

\author{
Jean GAUDANT ${ }^{*}$, Jesús Miguel SORIA2, Ignacio FIERRO² \& Simona SAINT MARTIN ${ }^{3}$
}

${ }^{1}$ USM 203 du Muséum national d'Histoire naturelle et UMR 7207 du CNRS, 17 rue du DocteurMagnan, F-75013 Paris, France; jean.gaudant@orange.fr

${ }^{2}$ Universidad de Alicante, Departamento de Ciencias de la Tierra y del Medio Ambiente, Apto 99, 03080 San Vicente del Raspeig, Alicante, Spain; jesus.soria@ua.es; nacho.fierro@ua.es

${ }^{3}$ Muséum national d'Histoire naturelle, UMR 7207 MNHN/CNRS/UPMC, Département Histoire de la Terre, 8 rue Buffon, 75005 Paris, France; simsmart@mnhn.fr

* Corresponding author

Gaudant, J., Soria, J.M., Fierro, I. \& Saint Martin, S. 2015. The Upper Miocene fish fauna of the Fortuna Basin, as observed in the surroundings of Abanilla (Murcia province, Spain). [La fauna de peces fósiles del Mioceno superior de la Cuenca de Fortuna, según se observa en los alrededores de Abanilla (provincia de Murcia, España)]. Spanish Journal of Palaeontology, 30 (1), 65-78.

\begin{abstract}
Fossil fishes are present at two different stratigraphical levels near Abanilla, in the Upper Miocene of the Fortuna basin (Murcia, Spain). The first site corresponds to a monospecific fossiliferous horizon, late Tortonian in age, which was present at La Serretilla before recent levelling works destroyed this outcrop. This horizon has mainly yielded fish remains and, exceptionally, articulated skeletons of clupeid fishes belonging to the species Sardina? crassa (Sauvage). The second fossiliferous site, which is stratigraphically situated in the basal part of the "Chicamo cycles", belongs to the lowermost Messinian. These strata, both marly and diatomaceous contain a juvenile fish fauna and correspond to a spawning area in which marine stenohaline fishes were breeding and where the newly hatched fishes were beginning their development. The diatoms of the fossiliferous horizons are clearly indicative of a fully marine salinity and exclude the possibility of hypo- or hyperhaline conditions. The composition of the Chicamo fish fauna looks very similar to that of the Campos del Río site and
\end{abstract}

\section{RESUMEN}

Los fósiles de peces se presentan en dos niveles estratigráficos diferentes cerca de Abanilla, en el Mioceno superior de la cuenca de Fortuna (provincia de Murcia, España). El primer yacimiento corresponde a un horizonte fosilífero monoespecífico, de edad Tortoniense superior, que se presentaba en La Serretilla antes de que los recientes trabajos de nivelación del terreno destruyeran el afloramiento. Este horizonte ha suministrado principalmente restos de peces $\mathrm{y}$, excepcionalmente, esqueletos articulados de peces clupeidos que pertenecen a la especie Sardina? crassa (Sauvage). El segundo yacimiento paleontológico, que se localiza estratigráficamente en la parte basal de los "Ciclos de Chicamo", pertenece al Messiniense inferior. Estos estratos, tanto margosos como diatomíticos, contienen una fauna de peces juveniles y corresponden a un área de desove en la cual peces marinos estenohalinos se reproducían y donde los nuevos peces recién nacidos se disponían a comenzar su desarrollo. Las diatomeas del yacimiento indican claramente 
characterizes marginal marine conditions that differ strikingly from those which, like the Columbares site, in the MurciaCartagena basin, are indicative of a connection to open sea.

Keywords: Teleostean fishes, spawning area, diatoms, Tortonian, Messinian. condiciones marinas francas, y excluyen la posibilidad de un contexto hipo o hiperhalino. La composición de la fauna de peces de Chicamo es muy similar a la del yacimiento de Campos del Río y caracteriza unas condiciones marinas marginales que difieren fuertemente de una conexión abierta hacia mar, como ocurre en el yacimiento de Columbares, en la cuenca de Murcia-Cartagena.

Palabras clave: Teleosteos, área de desove, diatomeas, Tortoniense, Messiniense.

\section{INTRODUCTION}

For over a century, fossil fishes from the Uppermost Miocene of Spain were only known in the Lorca basin, where articulated skeletons of adult fishes had been found by miners digging sulphur rich carbonates in the Serrata (Verneuil \& Collomb, 1856; Botella, 1868). More recently, one of us (Gaudant, 1995a) observed at Lorca, in the diatomitic intercalations, juveniles of a more diversified fish fauna dominated by the species Spratelloides gracilis (Schlegel) and interpreted these levels as spawning areas of teleostean fishes. It is also worth remembering that another, non diatomitic locality has yielded Messinian juvenile fishes near Campos del Río, approximately in the middle between Lorca and Abanilla (Gaudant et al., 1994).

A few years earlier, Müller (1986: 48) had reported the occurrence of fish skeletons, fish teeth and scales in the "Diatomit/Mergel-Wechsellagerung" (presently called "Chicamo cycles") outcropping near Abanilla, in the Fortuna basin, about $80 \mathrm{~km}$ NE of Lorca. Later, Müller \& Schrader (1989) described the diatom flora from these "Chicamo cycles", in which they identified about 30 species including planktonic diatoms (Thalassionema nitzschioides and Chaetoceros spores) considered to indicate "a highly productive upwelling environment".

However, it was more recently, during the preparation of the nannoplankton biostratigraphical study of the Upper Miocene of the Fortuna basin (Lancis et al., 2010) that a real interest arose for the juvenile fish skeletons that are present - although very scarce - in the two basal cycles of the "Chicamo cycles".

It should be emphasized that these three fish faunas from Lorca Campos del Río, and Abanilla "Chicamo cycles" strikingly differ from that described by Arambourg \& Montenat (1968) in the Messinian of the Sierra de Columbares, in the Murcia-Cartagena basin because, at Columbares, myctophids are so predominant that Arambourg was convinced of the bathypelagic character of these diatomites, an opinion that has been later contested (Gaudant, 1989).

\section{GEOLOGICAL SETTING}

The Fortuna Basin is located at the eastern end of the Betic Cordillera (southern sector of the Iberian Peninsula, Fig. 1A). The sedimentary infill of the basin encompasses a time span from the Tortonian to the Quaternary (Montenat, 1977), and overlies the contact between the two principal geological domains of the Betic Cordillera: the Internal Zones and the External Zones (Fig. 1B). From a tectonic point of view, the Fortuna Basin is affected by a SW-NE directed, sinistral strike-slip fault, which represents the major structure of the eastern Betic Cordillera (Fig. 1A). According to Tent-Manclús et al. (2008), this fault conditioned the palaeogeographic evolution of the basin throughout the late Miocene and Pliocene times, in addition to the current seismic activity of the area. During the Tortonian this basin was filled by marine sediments. At the Tortonian-Messinian transition, marine evaporitic sedimentation took place (Tortonian Salinity Crisis; Krijgsman et al., 2000). From the Messinian onwards, the Fortuna Basin became completely continental (Garcés et al., 2001).

\subsection{Stratigraphical Framework and chronology}

The main stratigraphic features of the sectors comprising the whole Fortuna Basin have been described and illustrated in the pioneering work by Montenat (1977), and subsequently in those of Santisteban Bové (1981) and Lukowski \& Poisson (1990). According to a recent contribution by Soria et al. (2005) the late Miocene stratigraphic record of the basin can be divided into four synthems (I to IV), or major units delimited by basin wide unconformities (Fig. 2).

Synthem I includes two lithostratigraphic units; a basin margin unit "Ventanas Calcarenites" - dominated by mixed carbonate and siliciclastic sandstones, locally made up of coral reefs, which was deposited on a shallow marine shelf; and a basin centre unit - the "Fortuna Marls" - represented 

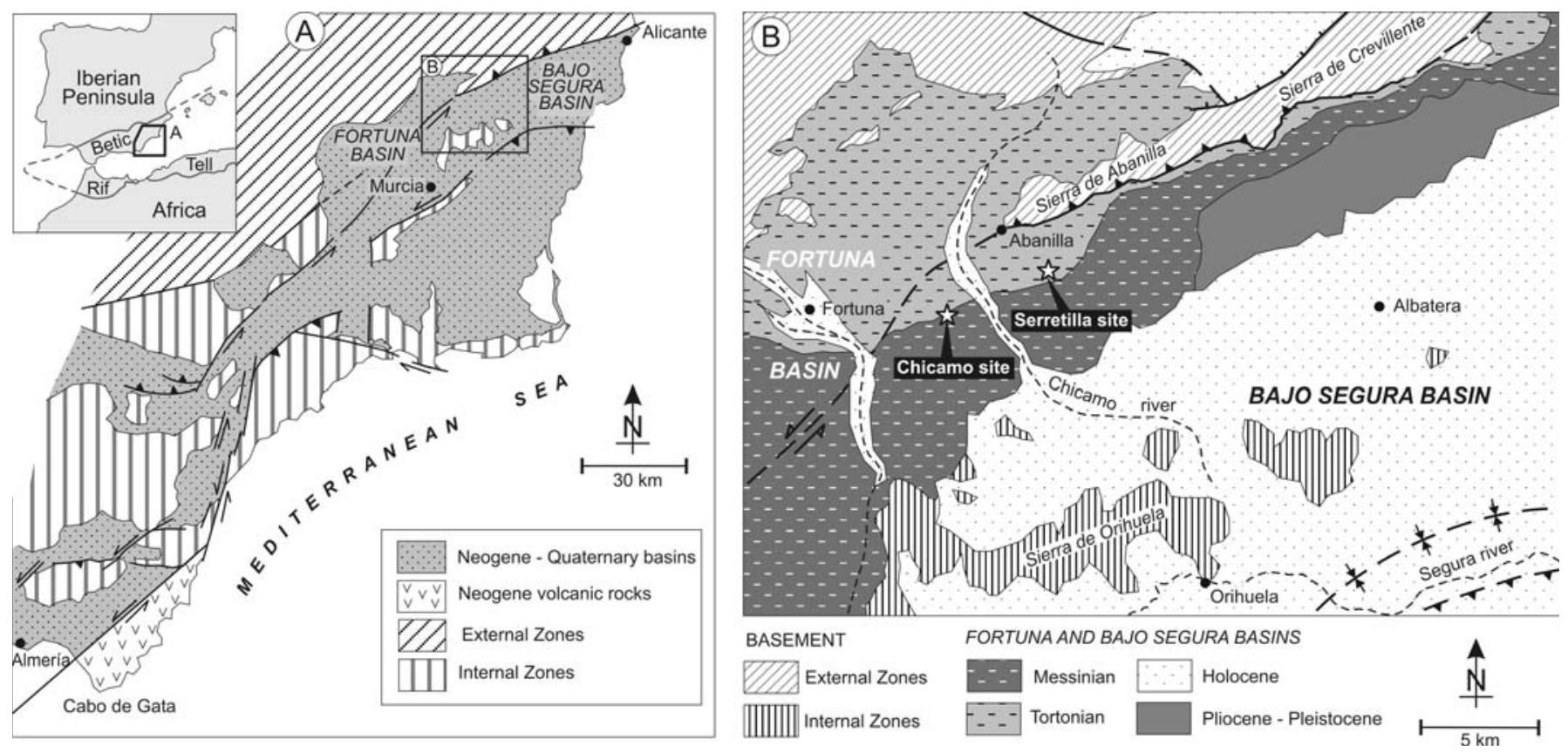

Figure 1. A) Geological map of the eastern end of the Betic Cordillera showing the position of the Fortuna Basin (after Montenat, 1990). B) Location of the fossil fish sites (Serretilla and Chicamo) in the Fortuna Basin.

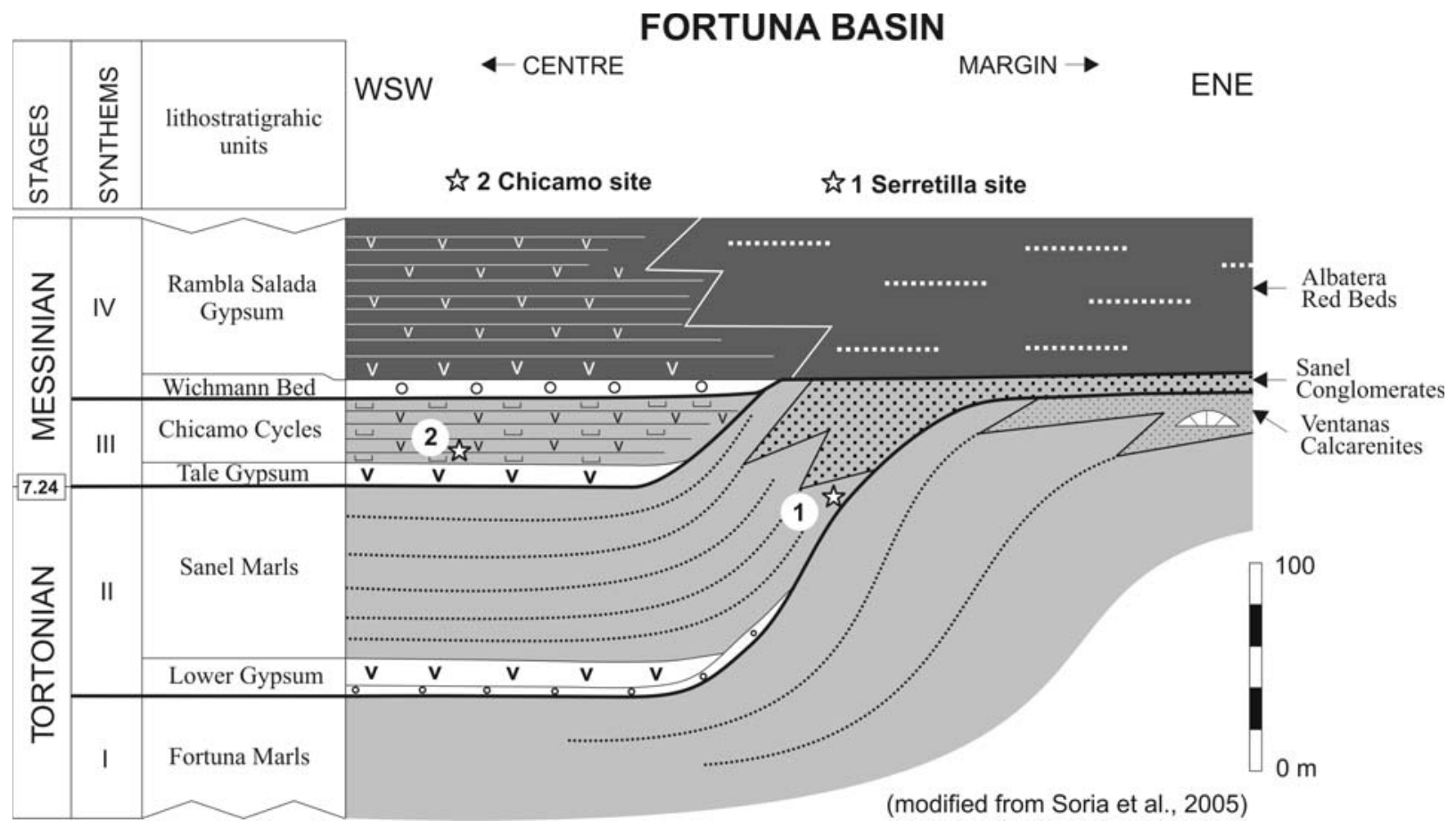

Figure 2. Stratigraphical architecture of the Fortuna Basin and position of the studied sites. See text for the explanation of the lithostratigraphic units.

by a thick succession of deep marine, planktonics-rich marls. The Fortuna Marls are unconformably overlain by conglomerates and shallow marine evaporites - the "Lower Gypsum" - which represent the basal sediments of the Synthem II. Results from Tent-Manclús et al.
(2008) indicate that these evaporites define the onset of the Tortonian Salinity Crisis. Above the evaporites, the rest of the synthem consists of coarse-grained deltaic deposits - the "Sanel Conglomerate" - which are laterally correlative to marine marls - the "Sanel Marls" - that crop 
out in the basin centre. Fine-grained calcareous sediments at the base of the Sanel Conglomerate bear a laminated limestone level that yields fossil fish remains (Fig. 3).

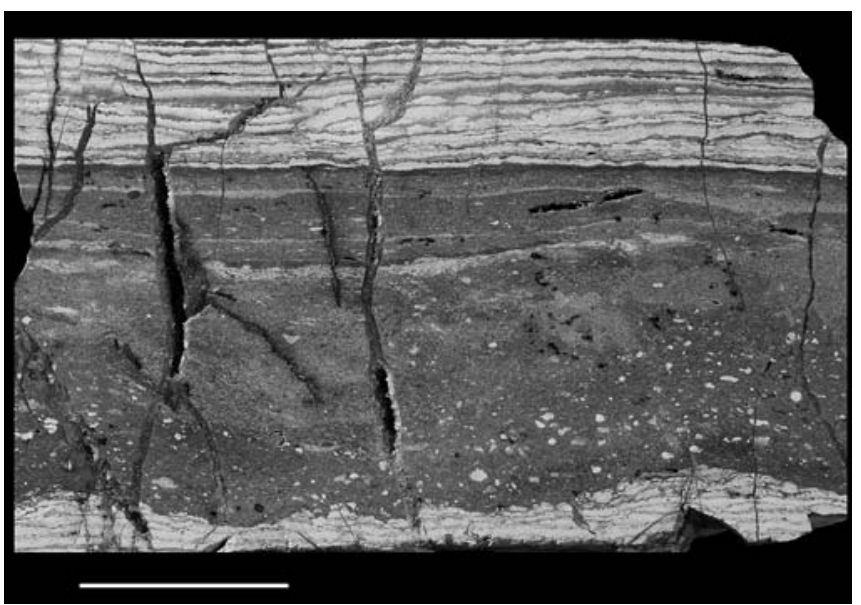

Figure 3. Section in the fossiliferous laminated limestone exposed at La Serretilla. The base of the sample shows the more or less regularly laminated limestone which was abruptly interrupted by the irruption of a greyish massive fine-grained calcareous sediment. This interruption provoked an erosion which was responsible for the irregular contact between the whitish laminated and the greyish massive sediment and for the presence in the last one of white flakes proceeding from the laminated whitish limestone. After the end of the deposition of the greyish finegrained sediment, quiet conditions prevailed again, allowing the deposition of the fossiliferous laminated sediment in which the white calcitic laminae have generally a thickness of 1-2 mm, whereas the thinner brownish ones are composed of dolomitic limestone Scale $2 \mathrm{~cm}$.

This white limestone, initially considered as a silexite, is herein referred to as the Serretilla site (Fig. 4), which provides the oldest fossil fishes in the Upper Miocene sediments recorded in the Fortuna Basin.

Synthem III is solely represented in the basin centre, above the "Sanel Marls". This synthem is composed of two stacked units: a basal one of laminated evaporites - the "Tale Gypsum" -, and an upper repetitive succession of marls, diatomites and gypsum beds: the "Chicamo Cycles". Up to five complete cycles (i.e., ending with a gypsum cap) are recognized in the studied section; a sixth cycle at the uppermost part is partially eroded below the overlying Synthem IV. At the Chicamo site, the fossil fishes are preserved in the diatomites of the two lower cycles (Fig. 5). Synthem IV contains a basal shallow marine conglomerate - the "Wichmann Bed" -, upon which a thick succession of lacustrine evaporites rests: the "Rambla Salada Gypsum".

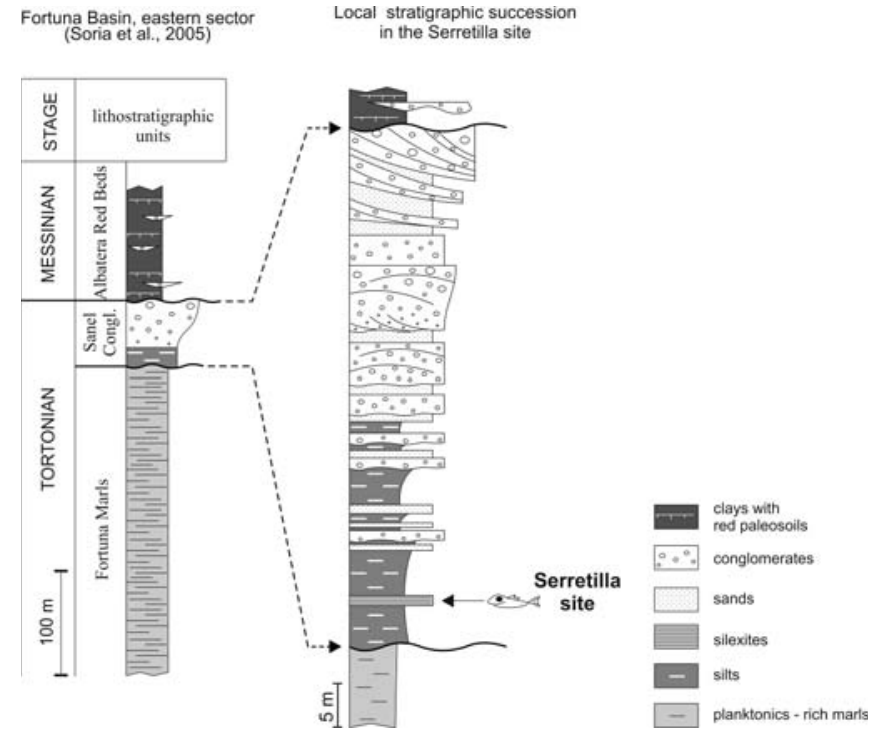

Figure 4. Lithological succession of the deltaic silts, sands and conglomerates (Sanel Conglomerates) where the Serretilla site is located.

Alluvial red clays and conglomerates - the "Albatera Red Beds" - represent the marginal sediments correlative to the lacustrine evaporites in the basin centre.

From a chronological standpoint, the recent biostratigraphic and magnetostratigraphic combined study by Lancis et al. (2010), supported by the regional stratigraphic correlation by Corbí et al. (2012), allow a precise dating of the four synthems described above (Figs 2, 5). In short, synthems I and II are Tortonian in age, and synthems III and IV are Messinian. This implies that the Serretilla site (located in the "Sanel Marls" of the Synthem II) fits in the late Tortonian, without further precise data on its exact chronostratigraphic position; however, the age of the Chicamo site (located in the lower "Chicamo Cycles" of the Synthem III) can accurately be placed at the top of the magnetic chron $\mathrm{C} 3 \mathrm{Bn}$, at a numerical age of 7.12 Ma (earliest Messinian).

\section{THE TORTONIAN FISHES FROM LA SERRETILLA}

When describing the upper part of the Sanel Member of the Los Baños Formation, Müller (1986, cf. p. 76) noted that "fish remains are common within the white layers in between the marls". He also figured in a section (Müller, 1986, fig. IV.5) a thin "weisse Lage mit Fischresten, dunkelgraue Mergel" [a white level with fish remains, and dark grey marl]. This strata is possibly the equivalent of the thinly laminated calcareous marly horizons alternating with detritic turbiditic intercalations observed at the base of the 


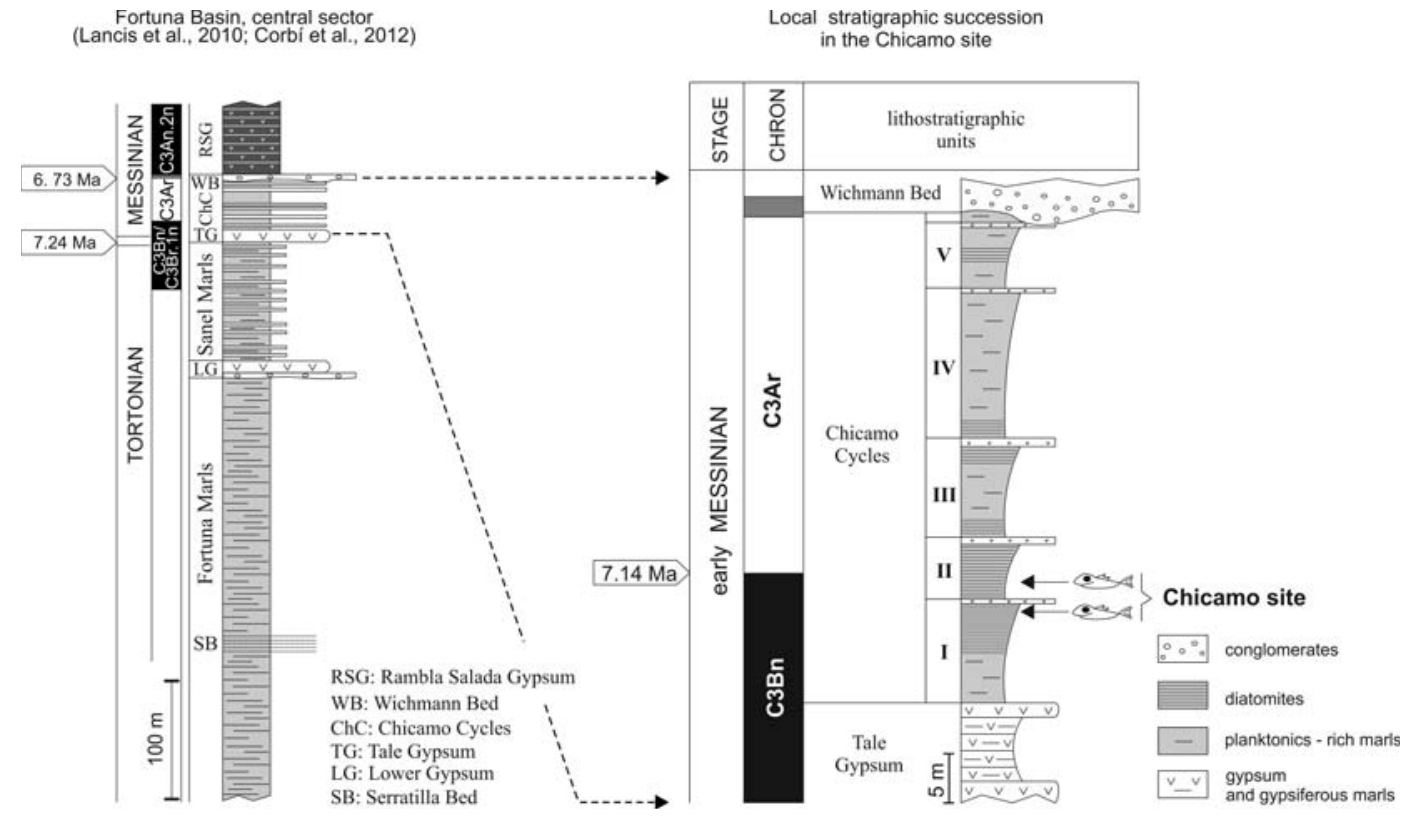

Figure 5. Repetitive succession of marls, diatomites and gypsum ("Chicamo Cycles") where the Chicamo site is located.

Serretilla hill, where they have mainly yielded fragments and exceptionally more or less complete skeletons of teleost fishes during a small excavation in 1992. Unfortunately, in the meantime, levelling works carried out in this area, situated at a short distance to the south of the "camino de Orihuela", have totally destroyed the old fossiliferous outcrop that had been excavated thanks to information provided by Carlos de Santisteban (Valencia University). Although the white laminae have a thickness generally ranging from 1 to $3 \mathrm{~mm}$, the detritic brownish laminae are always thinner. Microscopical examination of the white laminae with a scanning electronic microscope has shown that they mainly consist of small calcitic crystals that were originally the components of very small coccoliths. Rare coccoliths have also subsisted.

\subsection{Studied material}

A complete articulated skeleton (MNHNF-PTE 749D+G) and several fragments, including a small slab bearing the figured opercular region (MNHNF-PTE 750 to 756). These specimens are kept in the palaeontological collections of the National Museum of Natural History, Paris.

All the specimens collected at this outcrop are clupeid fishes that can be attributed to the species Sardina? crassa (Sauvage). All have a moderate size, as their standard length is always less than $100 \mathrm{~mm}$. No head is sufficiently well preserved for being described; however an opercular region (Fig. 6) shows an operculum, the width of which is about half its height. Its posterior outline is rather

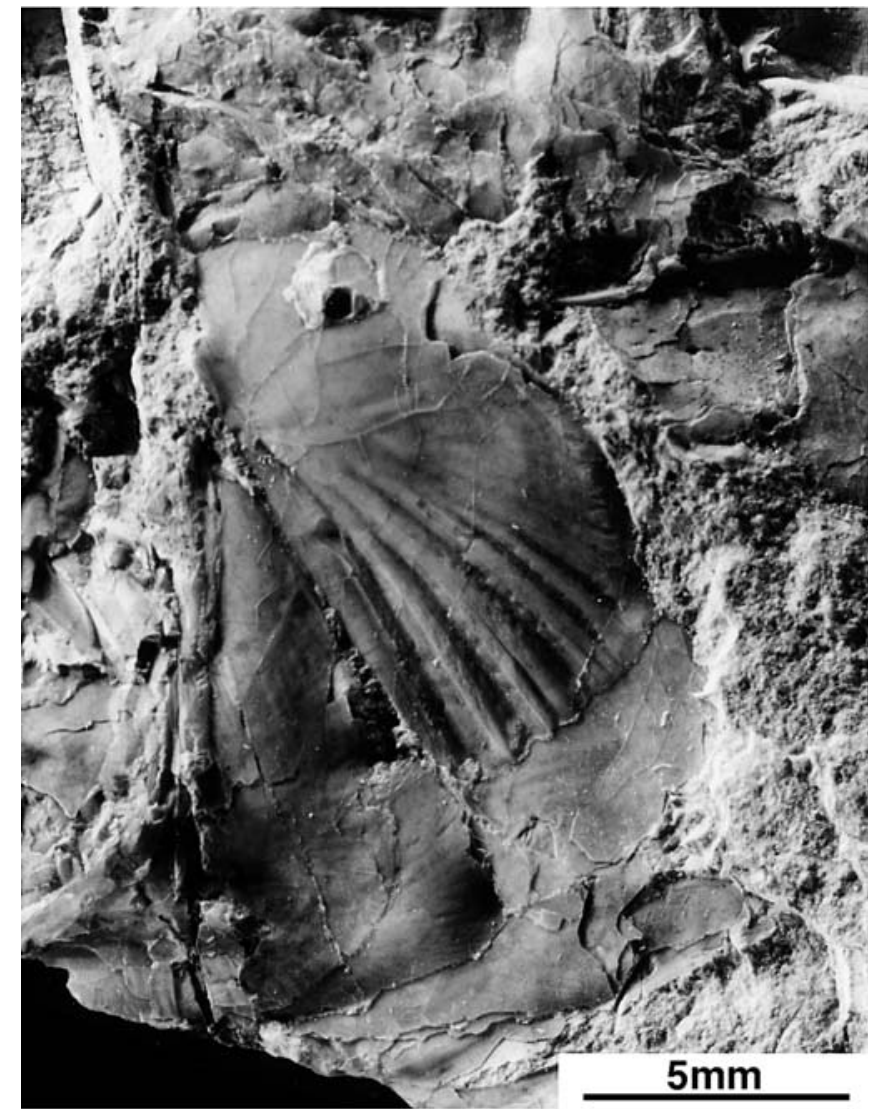

Figure 6. Sardina sp. Opercular region found in the Sanel member (late Tortonian) of La Serretilla, near Abanilla. Specimen MNHNF-PTE 751. 
convex. Its antero-ventral area is ornamented by five ridges radiating from an antero-dorsal point.

The body is elongate, its maximum height being about $15-20 \%$ of the standard length (Fig. 7). The vertebral column probably included slightly more than 40 vertebrae, 17 of which composed the postabdominal region. The forked caudal fin consisted of 19 principal rays, 17 of them being furcated. The dorsal fin is inserted in the middle of body, slightly behind the pelvic fins. The rather small anal fin is situated posteriorly: it begins well behind the base of the last dorsal ray. The pectoral fins have about 15 rays. The pelvic fins, which are small, are situated approximately in the middle between the base of the pectorals and the origin of anal.

The body is covered with cycloid scales. Their surface is divided by transversal grooves. No punctuation is present the species Sardina? crassa (Sauvage), which is widely distributed in the Upper Miocene of the Mediterranean basin. Although it occurs in well diversified fish faunas, such as Campos del Río including at least ten species, (Gaudant et al., 1994), it may also be found alone in unusual environments like in the Messinian intraevaporitic clay of the Sorbas gypsum quarry (Gaudant, 2008) or even associated with the euryhaline cyprinodontiform species Aphanius crassicaudus (Agassiz) in the Messinian lagoonal gypsum of Western Crete (Gaudant, 1980, 2014).

\section{THE MESSINIAN FISH FAUNA FROM THE "CHICAMO CYCLES"}
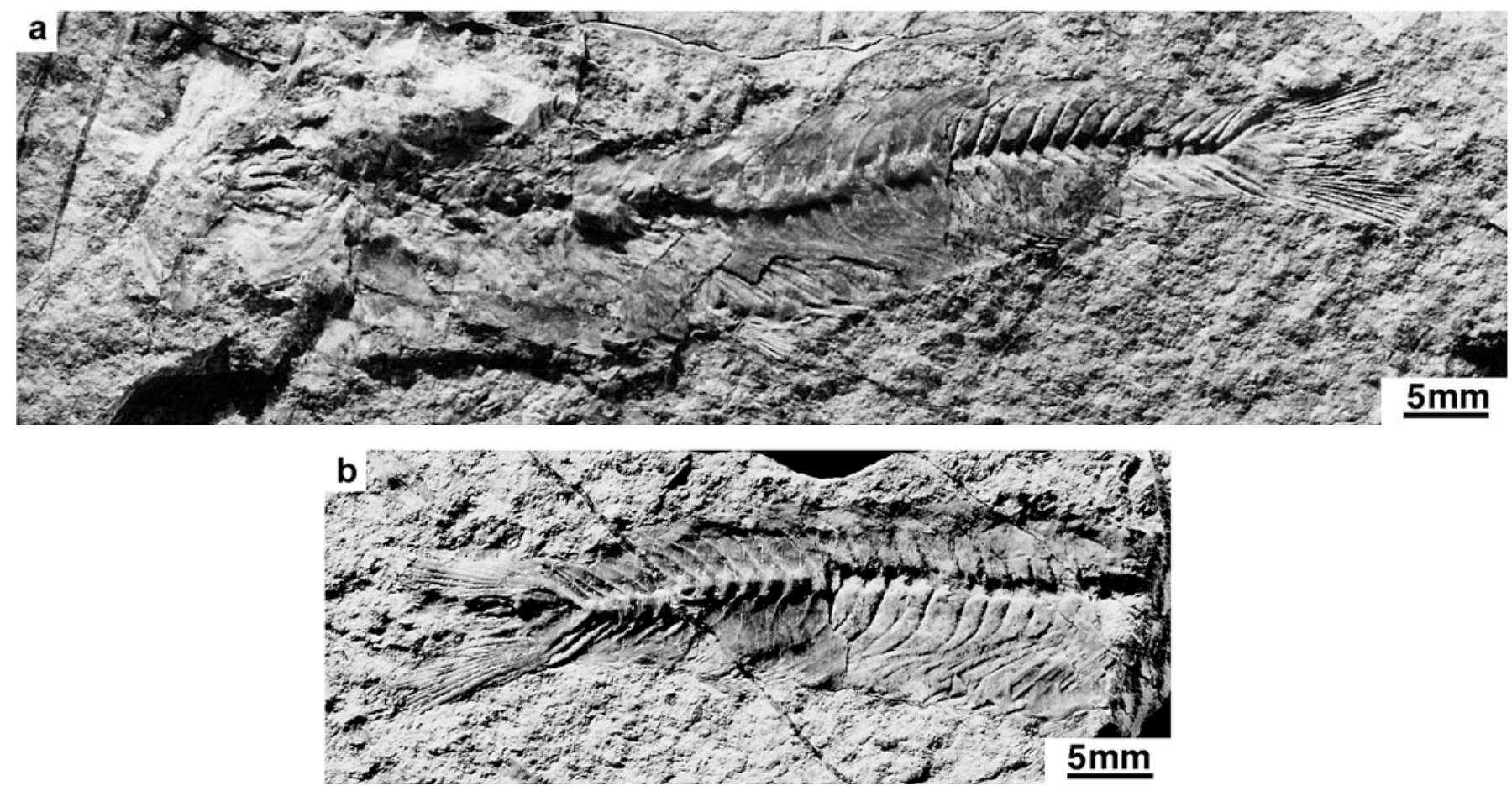

Figure 7. Sardina sp. General view of the most complete specimen found in the Sanel member (late Tortonian) of La Serretilla, near Abanilla. Specimen MNHNF-PTE 749D+G.

on their surface. A ventral keel made of smooth scutes is present in the abdominal region.

\subsection{Discussion}

According to the characters described above, especially the shape and ornamentation of the operculum, the composition of the vertebral column, the morphology of the scales and the presence of an abdominal ventral keel, it is clear that the Tortonian fossil fishes from La Serretilla belong to
The fossil fishes were collected in the laminated marly parts of the two lower cycles of the "Chicamo cycles" outcropping above the right bank of the Chicamo river $\left(38^{\circ} 11^{\prime} 011^{\prime \prime} \mathrm{N} ; 01^{\circ} 03 ’ 31^{\prime \prime} \mathrm{W}\right)$, at about $3 \mathrm{~km} \mathrm{S-SW}$ of Abanilla. The occurrence of fossil fishes is extremely rare in the lowest cycle and is slightly less scarce in the second cycle.

Studied material. Sixty small, generally more or less incomplete fish skeletons and five rather well preserved 
scales of a clupeid fish were collected in the lower "Chicamo cycles". They are kept in the repository of the Museo Arqueológico de Murcia where they have received the catalogue numbers MAM-CHI-1 to 65 .

Order CLUPEIFORMES Bleeker, 1859

Family Clupeidae Cuvier, 1817

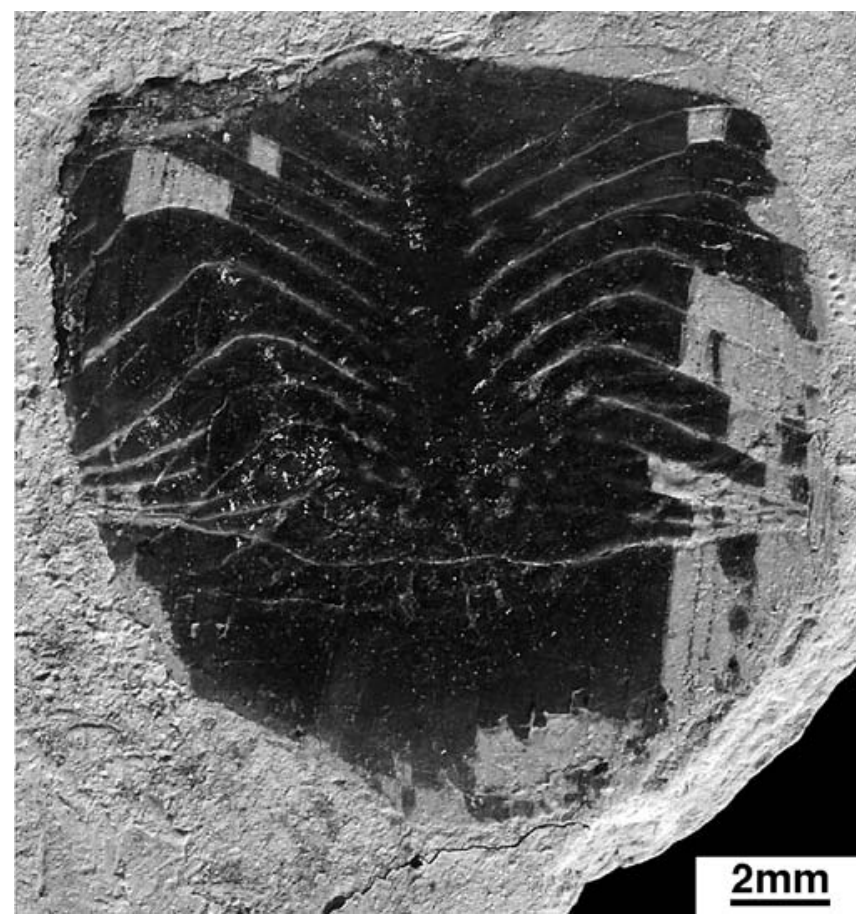

Figure 8. Alosa sp. Isolated scale. Specimen MAM-CHI-13, from the "Chicamo cycles".

Genus Alosa Linck, 1790

\section{Alosa sp.}

(Fig. 8)

Several rather large scales of clupeid fishes were found in the lowest "Chicamo cycles". All are similar to that figured in Fig. 8. They exhibit two symmetrical series of more or less transverse furrows. Additionally, punctiform depressions are present in their central region. These deciduous scales are indicative of the presence of rather large shads during the deposition of the diatomaceous marls.

Genus Spratelloides Bleeker, 1851

$$
\text { Spratelloides gracilis (Schlegel, 1846) }
$$

(Fig. 9)

This species is by far the most abundant in the material collected in the "Chicamo cycles" with $46.7 \%$ of the total number of more or less complete fish skeletons. It is mainly represented by juvenile specimens having a standard length ranging from 12.5 to $27.5 \mathrm{~mm}$, with the highest frequency observed between 15 and $25 \mathrm{~mm}$, whereas three specimens had a standard length comprised between 35 and $40 \mathrm{~mm}$ (Fig. 14).

The best preserved specimen (MAM-CHI-33 D+G; Fig. 8) is a small fish having a standard length of 19.5 $\mathrm{mm}$. It is elongated: the maximum height of body is only $1 / 10$ of the standard length. The head is almost two times longer than high. Its length is comprised four times in standard length. The orbit is rather large: its diameter is about $1 / 3$ of the head length. The mandible is rather short: it articulates with the skull under the anterior part of the orbit. The opercular region is moderate: its width is about $1 / 3$ of the head length.

The vertebral column consists of about 48 vertebrae. The caudal fin, which was forked, is incompletely preserved, as its distal part is missing. The dorsal fin is inserted in the middle of body. It is composed of nine rays. The anal fin is situated posteriorly, the anteanal distance being about $3 / 4$ of standard length. It is never completely preserved. The pectoral fins are inserted low on the flank. The pelvic fins are situated behind the middle of body, approximately under the middle of the dorsal fin base. The body is covered with cycloid scales showing on their surface parallel circuli disposed vertically. No ventral keel made of scutes is present in front of the anal fin.

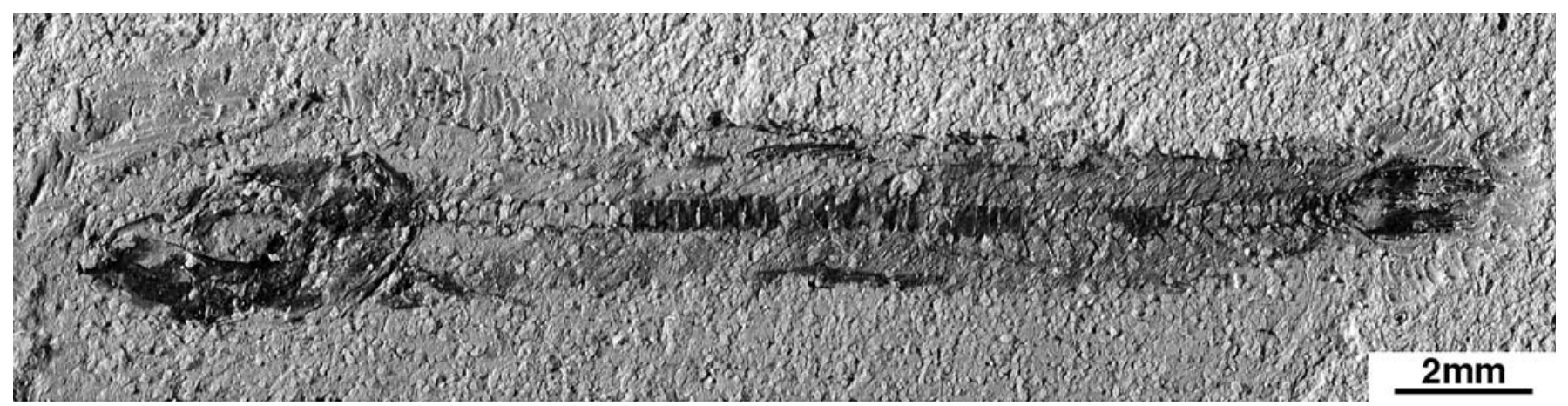

Figure 9. Spratelloides gracilis (Schlegel). General view of specimen MAM-CHI-33D, from the "Chicamo cycles". 
Discussion. Because of their small size, the specimens of this species are generally imperfectly preserved. However the main meristic and morphometric characters observed on the best preserved specimens do not significantly differ from those of the representatives of the species Spratelloides gracilis (Schlegel) from the Messinian localities of the marginal basins of the Betic region. This species is abundant in the diatomitic layers of La Serrata section of the Lorca basin (Gaudant, 1995a) and in the laminated marls of Campos del Río where the collected specimens have generally a similar size, mainly ranging between 15 and $25 \mathrm{~mm}$ (Gaudant et al., 1994).

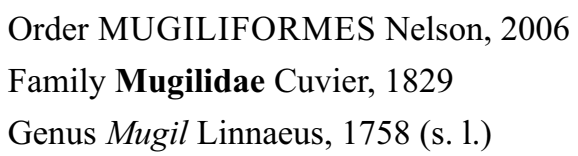

Mugil sp.

(Fig. 10) spines are preserved. They are supported by a rather long and strong pterygiophore that intercalates between two neurapophyses. The second dorsal fin, which is rather small, is poorly preserved. It clearly begins behind the base of the last anal ray. The anal fin is opposed to the gap separating the two dorsal fins. It begins with three spines, the second one being both the longest and the strongest. The number of anal rays is unknown. The first pterygiophore, which is long and robust, articulates with the first postabdominal haemapophyse. The pectoral fins are inserted near the middle of the flank, just under the vertebral column. They consist of about 15 rays. The pelvic fins, which are moderate, are inserted in subthoracic position. The pelvic bones are connected with the pectoral girdle. The scales covering the body are not well enough preserved to be described.

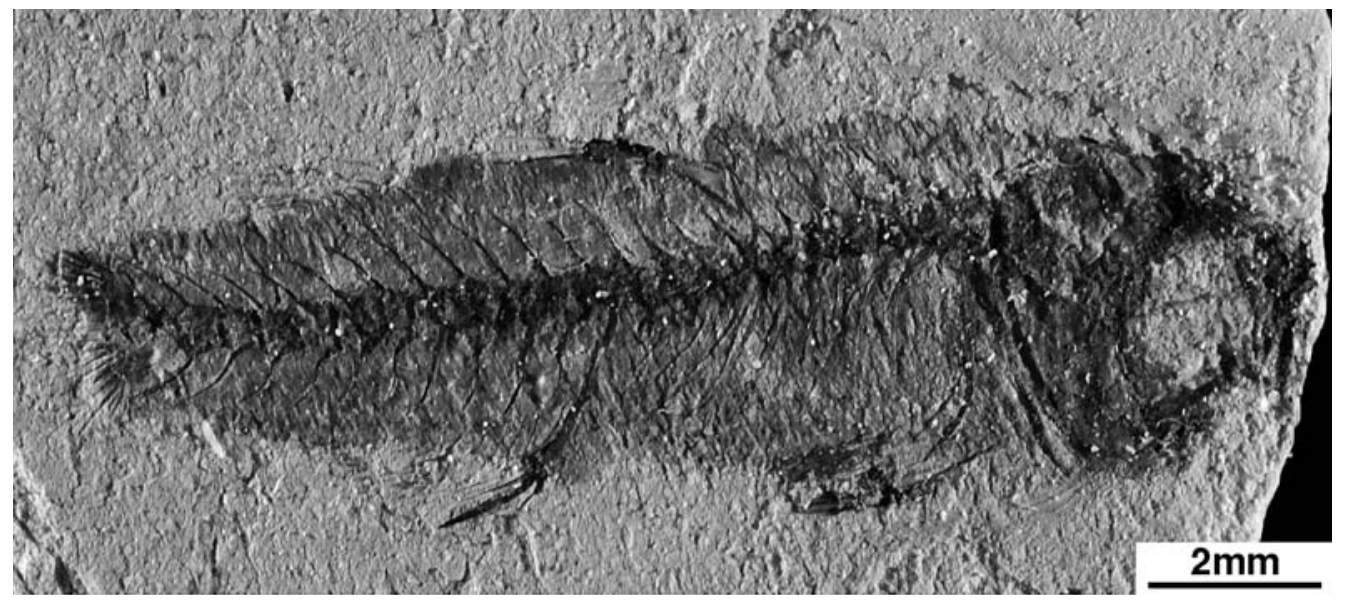

Figure 10. Mugil sp. General view of specimen MAM-CHI-34G, from the "Chicamo cycles".

Only one juvenile specimen (MAM-CHI-34 D+G; Fig. 10), having a standard length of $14 \mathrm{~mm}$ indicates the occurrence of mugilids in the "Chicamo cycles". It has a rather thick-set body with a maximum height of $32 \%$ of the standard length. The head is moderate: its length is less than $30 \%$ of the standard length. Although its state of preservation is rather poor, it is possible to recognize its large, massive frontal, and the rather large orbit which is crossed near its middle by the parasphenoid. The opercular region, which is rather narrow, has a width which is about $1 / 4$ of the head length. The mandible articulates with the skull under the middle of the orbit.

The vertebral column is composed of 11-12 abdominal and 12 postabdominal vertebrae. There are nine pairs of rather robust and relatively short pleural ribs. The caudal fin is not preserved. The first dorsal fin is inserted slightly behind the middle of body. Only its first two robust
Discussion. The juvenile specimen described above has approximately the same size as that found at Campos del Río. However, it slightly differs from the later by its less elongate body and by the possession of one postabdominal vertebra less. Because of its imperfect state of preservation, it is impossible to ascribe this specimen to any species, although the composition of its anal fin is similar to that known in the recent species $M$. cephalus Linnaeus.

Order PERCIFORMES Bleeker, 1859

Family Carangidae Rafinesque, 1815

Genus ?Trachurus Rafinesque, 1810

?Trachurus sp.

(Fig. 11) 
This species is the second most abundant found in the "Chicamo cycles", with 15 more or less complete specimens ( $25.0 \%$ of the fish fauna). Their standard length ranges from 6 to $19.5 \mathrm{~mm}$, the most important frequency being observed between 6 and $15 \mathrm{~mm}$.

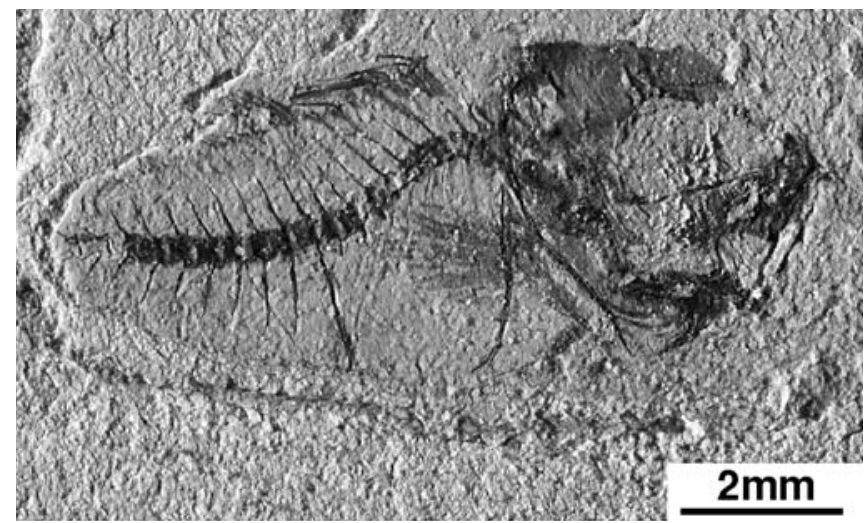

Figure 11. ?Trachurus sp. General view of specimen MAMCHI-37G, from the "Chicamo cycles".

The figured specimen (MAM-CHI-37G; Fig. 11) has a standard length of $11 \mathrm{~mm}$. The head, which is as high as long is characterized by the rather large orbit which is crossed by the parasphenoid near its lower third. The articulation of the mandible with the skull is situated under the middle of the orbit. The opercular region is rather narrow: its width equals about $1 / 4$ of the head length.

The vertebral column consists of about 24 vertebrae, 14 of them being postabdominal.

The caudal fin is only preserved on specimen MAMCHI-42. It is deeply divided into two lobes. The first dorsal fin that included more than six rather short spines is inserted shortly behind the head. It is supported by at least six pterygiophores. The second dorsal fin begins by one short spine. It is incompletely preserved: only ten rays could be observed. The anal fin is not preserved but its first pterygiophore is present, with its distal end projected forward. The pectoral fins are situated rather high on the flank. They consist of about 15 rays. The pelvic fins, which are small, are inserted below the pectorals. They are supported by the pelvic bones that articulate with the pectoral girdle.

Discussion. The morphology of these young fishes, and especially the fact that their anterior dorsal fin consists of rather short spines suggests that they are similar to those previously described from the Messinian of Campos del Río as ?Trachurus Rafinesque (Gaudant et al., 1994). In fact, the lack of ossified scutes along the lateral line is not taxonomically significant for discriminating both genera because they appear at a later stage during the growth of the fishes.

Family Trichiuridae Rafinesque, 1810

Genus Lepidopus Gouan, 1770

\section{Lepidopus sp.}

(Fig. 12)

A complete juvenile specimen and five fragments of Lepidopus Gouan were found in the "Chicamo cycles". The complete skeleton (MAM-CHI-39D+G; Fig. 12) has a standard length of $31.5 \mathrm{~mm}$. Its body, which is extremely elongated (more or less ribbon like) has a maximum height which is only $8 \%$ of standard length.

The head is relatively large and elongate: its length is included 4.5 times in the standard length and is the double of its maximum height. The orbit is rather small: its horizontal diameter is less than $1 / 5$ of the head length. The antorbital region is well developed: it constitutes more than $1 / 3$ of the head length. The mandible which

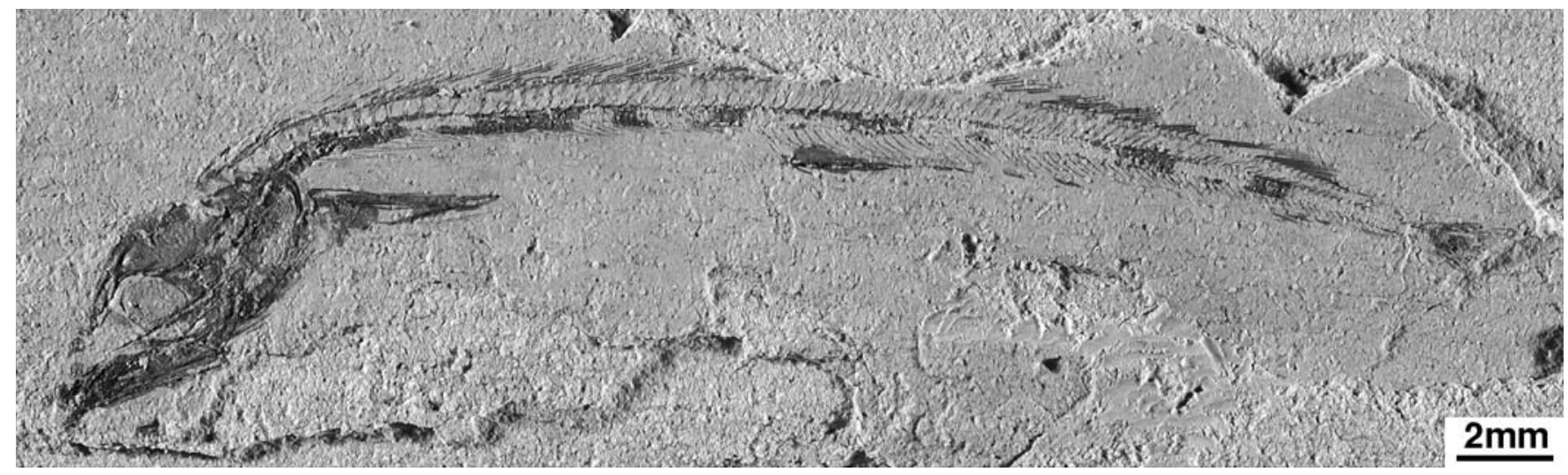

Figure 12. Lepidopus sp. General view of specimen MAM-CHI-39D, from the "Chicamo cycles". 
articulates with the skull under the posterior part of the orbit, is long and low. The premaxillary, which is partly preserved, bears on its oral edge two rather strong fangs. The operculum is wider than high; its width is about one third of the head length.

The vertebral column is composed of about 110 vertebrae: about 40 abdominal and 70 postabdominal. Their centra are not completely ossified. The caudal fin was small. It is incompletely preserved. The dorsal fin was probably composed of about 90 rays. The composition of the anal fin is unknown. The pectoral fins consisted of about ten rays. The pelvic fins are inserted in a thoracic position. The body is naked.

Discussion. Two species of Lepidopus have been identified in the Messinian of the western Mediterranean: L. albyi Sauvage was first described at Licata (Sicily) (Arambourg, 1925) and L. proargenteus Arambourg, 1927 in the "marnes des Planteurs" at Oran (Algeria) (Arambourg, 1927). The main character which may be used for comparing the juvenile specimen from the Chicamo cycles with the two species of Lepidopus known in the Messinian of the Mediterranean basin is the composition of the vertebral column. However, if the number of its abdominal vertebrae is approximately the same as that of $L$. proargenteus Arambourg, the number of postabdominal vertebrae of this species is unknown. On the other hand, the specimen from Chicamo has several abdominal vertebrae more than $L$. albyi Sauvage (about 40 against 35-36), the number of their postabdominal vertebrae is more or less similar (70 against at least 70 in L. albyi Sauvage). Consequently, as the morphology of the fangs borne by the premaxillary is unknown, there is no decisive argument for determining the Chicamo juvenile at the specific level.

Family Gempylidae Gill, 1862

Gempylidae indet.

(Fig. 13)

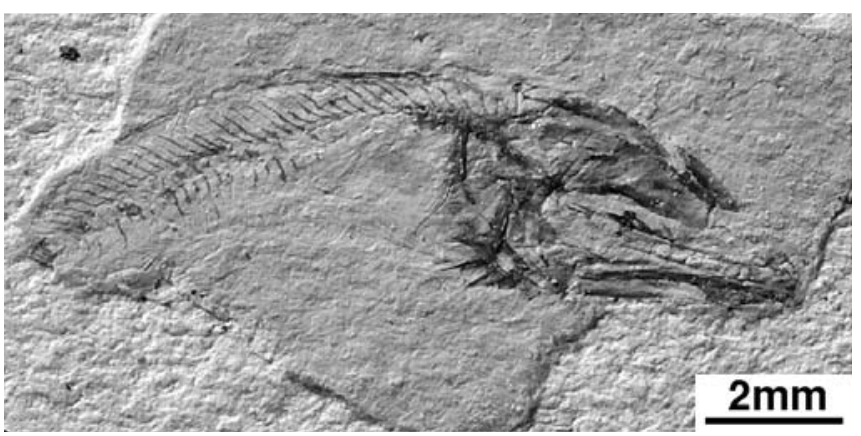

Figure 13. Gempylidae indet. Larval stage showing the spiny preoperculum. Specimen MAM-CHI-14, from the "Chicamo cycles".
The specimen MAM-CHI-14 shows the head and the anterior part of the elongate body of a small fish characterized by its rather long head having a length of $5.5 \mathrm{~mm}$, a measurement corresponding to an estimated standard length of about $25 \mathrm{~mm}$ (Fig. 13). This juvenile head, the maximum height of which is less than $60 \%$ of its length shows a long lower jaw measuring about $80 \%$ of this dimension. Several large teeth were present on the anterior part of the oral process. Its preoperculum has its postero-ventral angle ornamented by three rather long spines. The maximum width of the subtriangular operculum is situated in its upper part.

Discussion. Although it is difficult to determine the relationships of this small incomplete and imperfectly preserved fish, sharing a somewhat similar general morphology with the genus Lepidopus Gouan, this specimen evidently differs from it by the presence of several large teeth on the anterior part of the dentary, and also by its operculum which is smaller than the wide operculum of Lepidopus. Consequently, it is here suggested that this specimen may represent a larval stage of a gempylid.

Order PLEURONECTIFORMES Bleeker, 1859

Family Soleidae Bonaparte, 1833

Genus ?Microchirus Quensel, 1806

?Microchirus sp.

(Fig. 14)

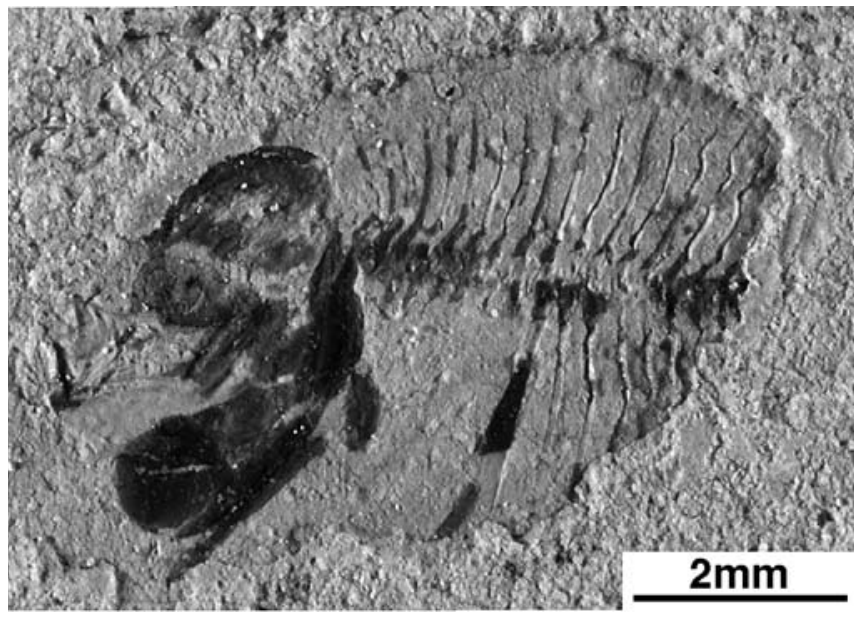

Figure 14. Microchirus? sp. General view of specimen MAMCHI-38; from the "Chicamo cycles".

An incomplete specimen (MAM-CHI-38; Fig. 14) gives evidence of the occurrence of Pleuronectiformes in the Fortuna basin during the deposition of the "Chicamo 
cycles". This very small fish shows a head which is only $3 \mathrm{~mm}$ long, the abdominal region and nine postabdominal vertebrae.

The head is higher than long. Its skull roof is convex in lateral view. The orbit is rather large as its diameter is about one third of the head length. The size and the position of the orbit clearly indicate that this specimen had not yet undertaken the metamorphosis. The opercular region looks narrow. The mandible, which is short, articulates with the skull in front of the anterior edge of the orbit.

There are 9 abdominal vertebrae. Their centra bear long neurapophyses. No pleural rib is visible. The postabdominal vertebrae bear long neurapophyses and haemapophyses.

The dorsal has not left any trace in the sediment. The anal fin is not preserved, except for its strong haemaxanal complex, the distal part of which is sensibly inclined forward.

No trace of scale is visible.

Discussion. The incompleteness of this very small juvenile specimen makes difficult its determination among the order Pleuronectiformes, especially because of the lack of knowledge of the front part of the dorsal fin. However, the number of its abdominal vertebrae may suggest some similarity with the soleid genus Microchirus Bonaparte.

\section{PALAEOECOLOGICAL INTERPRETATION OF THE MESSINIAN FISH FAUNA OF THE "CHICAMO CYCLES"}

The marine fish fauna collected in the lower part of the "Chicamo cycles" consists of articulated skeletons belonging to seven taxa (two of them are left undetermined), plus isolated scales of Alosa. This may be interpreted as suggesting a restricted environment, although the composition of the diatom flora is indicative of a direct oceanic influence, as shown by the occurrence of several upwellings markers.

The quantitative study of this fish fauna (Table 1) shows that the species Spratelloides gracilis (Schlegel) is dominant with $46.7 \%$ of the collected specimens, against $25 \%$ for the carangid ?Trachurus sp., the third component being Lepidopus sp. with $11.7 \%$. All the other components have only one representative. It should be noted that no bathypelagic fish is present in this fish fauna, a situation which is similar to that known in the Messinian of Campos del Río.
Table 1. Quantitative composition of the fish fauna from the "Chicamo cycles".

\begin{tabular}{lcc}
\hline Taxa & Items & \% \\
\hline Spratelloides gracilis & 28 & 46.7 \\
?Trachurus sp. & 15 & 25.0 \\
Mugil sp. & 1 & 1.7 \\
Percoidei indet. & 6 & 10.3 \\
Lepidopus sp. & 6 & 10.3 \\
Gempylidae indet. & 1 & 1.7 \\
?Microchirus sp. & 1 & 1.7 \\
\hline
\end{tabular}

The second significant character of this fish fauna is that, with the exception of the deciduous scales of Alosa which belonged to larger animals, it is only composed of juveniles as all of the collected skeletons have a standard length smaller than $40 \mathrm{~mm}$ (Fig. 15). This small size is quite remarkable in the carangid ?Trachurus sp., the representatives of which have a standard length ranging from 6 to $19.5 \mathrm{~mm}$, their highest frequency being observed between 5 and $15 \mathrm{~mm}$, a situation which is similar to that observed at Campos del Río whereas the specimen found in the marls from Lorca, figured by Sauvage (1875) and Arambourg (1927), reaches about $140 \mathrm{~mm}$. Additionally, except for one hyperostosed fragment which was from a larger fish (Meunier et al., 2010, Fig. 4B), the standard length of Lepidopus sp. Arambourg ranges from 17 to $31.5 \mathrm{~mm}$ although adult specimens of this species possibly measured more than one metre (Arambourg, 1927).

Consequently, the diatomitic marls of the "Chicamo cycles" may be considered as a spawning area for some teleost fishes living in the littoral zone. This is fully in agreement with the biology of the recent species which have a direct relationship with the identified fossil ones. For example, Spratelloides gracilis (Schlegel) is a recent epipelagic species living in the Indo-Pacific region, from Japan to the Red Sea. Carangids and especially the recent species of the genus Trachurus Rafinesque are also epipelagic fishes which are spawing in the littoral zone. The recent species of Mugil Linnaeus generally live in the shallow waters of the littoral zone where they also spawn. A similar situation is known among soleids, as already noted at Hurchillo (Gaudant et al., 2001). Although it is well known that the recent species Lepidopus caudatus (Euphrasen) migrates nearer to the shore for spawning, it had hitherto never been possible to observe such extremely young juvenile specimens of Lepidopus Gouan in the Upper Miocene of the Mediterranean.

To conclude, the fish fauna of the "Chicamo cycles" suggests that the fossiliferous diatomitic marls were deposited near the shore, in a marine rather restricted environment, although some markers of "upwellings" are present in the diatom flora. The interruption of the connexion with the sea produced in every cycle, an 
increase of salt content responsible for the disappearance of the fishes and, finally, the precipitation of evaporites.
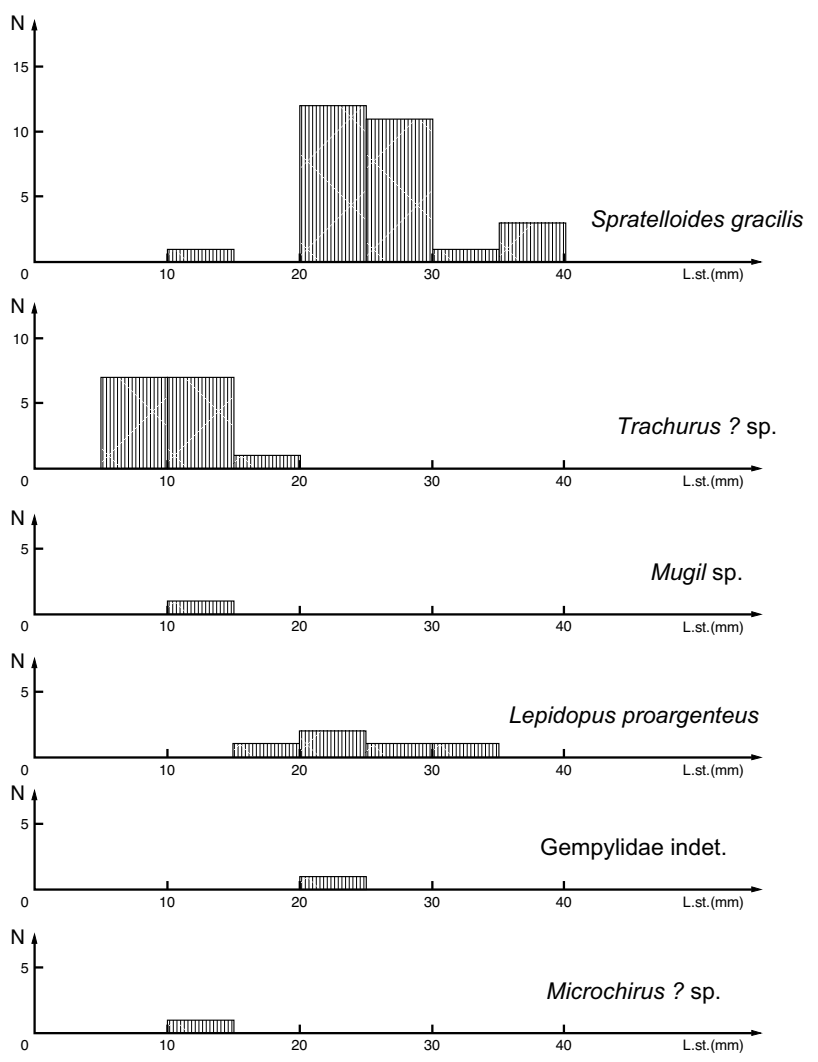

Figure 15. Histogram of standard lengths of the fossil fishes from the "Chicamo cycles".

\section{A REEXAMINATION OF THE DIATOM FLORA OF THE "CHICAMO CYCLES"}

The diatom flora of the "Chicamo cycles" was first studied by Müller \& Schrader (1989) who interpreted the "alternating diatomaceous and barren well-laminated marls in the Rio Chicamo Diatomites" as resulting from "changes between an estuarine (high productivity) and antiestuarine (low productivity) circulation pattern". However, as the fish fauna can hardly been interpreted as estuarine because it includes stenohaline taxa such as ?Trachurus sp. and Lepidopus sp., it appeared necessary to reexamine the composition of the diatom flora of the strata having yielded fish skeletons.

The studied diatom flora includes 24 genera (16 centric and 8 pennate) represented by 39 species ( 30 centric and 9 pennate). Among the last ones, Nitzschia is represented by two species, whereas Thalassiosira, Coscinodiscus and Actinocyclus are the most diversified centric diatoms. The planktonic species Thalassionema nitzschioides is the major component of the two studied diatom assemblages with percentages of $56.2 \%$ and $62.3 \%$, whereas Thalassiothrix longissima reaches only $20 \%$ and $17.4 \%$. The following relatively frequent species are the spores of Chaetoceros with $8.7 \%$ and $10.2 \%$ and Rhizosolenia hebetata with $6.5 \%$ in both samples.

It must be emphasized that neritic and planktonic species are overwhelmingly dominant in the studied samples with $99.5 \%$ of the total assemblage, whereas only three benthic species were identified: Cocconeis scutellum, Bacillaria paradoxa and Diploneis bombus. All the taxa are indicative of normal marine salinity conditions. The dominance of Thalassionema nitzschioides and Thalassiothrix longissima accompanied by Chaetoceros spores indicates the occurrence of coastal upwellings, a process that has already been invoked by Müller \& Schrader (1989) in the Fortuna basin.

From a palaeoclimatological point of view, cosmopolitan species (Thalassionema nitzschioides, Rhizosolenia hebetata, Actinocyclus ehrenbergii, Actinoptychus senarius, Coscinodiscus obscurus) constitute the major part of the total assemblage. They are mixed with the warm water species Coscinodiscus radiatus, Thalassiosira oestrupii, T. eccentrica, T. lineata, Thalassiosira cf. lineata, T. symbolophora, and also with some cold water species like Thalassiothrix longissima.

Finally, in addition to diatoms, silicoflagellates, ebridians and siliceous spicules of dinoflagellates known as Actiniscus are frequently observed. Although their occurrence is poorly known in the Messinian - it was hitherto only mentioned by Dumitrică (in Ryan et al., 1973) from the DSDP sites 133 and 134 drilled in the Sardinia slope and the Balearic abyssal plain -, the species Actiniscus pentasterias is mentioned for the first time in the studied samples from the Chicamo cycles of Abanilla.

\section{CONCLUSION}

Among the many fossil fish localities already known in the Upper Miocene of Spain, it is evident that the fish fauna from the "Chicamo cycles" exhibits important similarities with those of two other marginal basins of the Eastern Betics: Lorca and Campos del Río. All of them have mainly or exclusively yielded small juvenile specimens, although rather scarce large adults have also been found at Lorca, mainly but not only, in the marly beds intercalated between the fossiliferous diatomitic levels. In spite of some differences between them, these three localities are indicative of very shallow environments and may be considered as spawning areas, as shown by the smallest fishes which are sometimes still at a larval stage, such as the flatfishes that have not yet lost the symmetry of their 
skull, whereas other ones have still uncompletely ossified vertebral centra.

It should be emphasized that the composition of these fish faunas differs strikingly from that of localities like Columbares, in the Murcia-Cartagena basin, that had an open connexion to the deep sea, as demonstrated by the high percentage of myctophid fishes (Gaudant, 1995b).

\section{ACKNOWLEDGEMENTS}

The authors are grateful to Carlos de Santisteban-Bové (Valencia Universiy), who showed the fossiliferous outcrop of La Serretilla to the first author in 1992. They acknowledge Hugo Corbí, Carlos Lancis, José-Enrique Tent-Manclús (Alicante University) who took part in the first excavation made in 2009 in the "Chicamo cycles" and the team of the Museo Paleontológico de Elche, for supporting the present study. The excavations in the "Chicamo cycles" carried out in 2009 and 2011 were authorized by the Dirección general de Bienes Culturales de la Región de Murcia. Matias Freudental corrected the English. The first author acknowledges Giorgio Carnevale who helped identifying the incomplete gempylid, and the anonymous reviewer for his advices.

\section{REFERENCES}

Arambourg, C. 1925. Révision des poissons fossiles de Licata (Sicile). Annales de Paléontologie, 14, 39-96.

Arambourg, C. 1927. Les poissons fossiles d'Oran. Matériaux pour la Carte géologique d'Algérie, $1^{\mathrm{e}}$ série, Paléontologie, 6.

Arambourg, C. \& Montenat, C. 1968. Le gisement de poissons fossiles du Miocène supérieur de Columbares (province de Murcia, Espagne). Comptes Rendus de l'Académie des Sciences, Paris, 266 (D), 1649-1651.

Botella, F. de 1868. Descripción geológica-minera de las provincias de Murcia y Albacete. Imprensa del Colegio nacional de Sordo-Mudos y de Ciegos, Madrid.

Corbí, H., Lancis, C., García-García, F., Pina, J.A., Soria, J.M., Tent-Manclús, J.E. \& Viseras, C. 2012. Updating the marine biostratigraphy of the Granada Basin (central Betic Cordillera). Insight for the Late Miocene palaeogeographic evolution of the Atlantic - Mediterranean seaway. Geobios, 45, 249-263.

Garcés, M., Krijgsman, W. \& Agustí, J., 2001. Chronostratigraphic framework and evolution of the Fortuna basin (Eastern Betics) since the Late Miocene. Basin Research, 13, 199-216.

Gaudant, J. 1980. Sur la présence d'Alosa crassa Sauvage (Poissons téléostéens, Clupeidae) dans les gypses messiniens de Crète occidentale. Proceedings of the koninkijke Nederlandse Akademie van Wetenschappen, (B), 83, 263-268.

Gaudant, J. 1989. Poissons téléostéens, bathymétrie et paléogéographie du Messinien d'Espagne méridionale. Bulletin de la Société géologique de France, (8), 5, 1161-1167.

Gaudant, J. 1995a. Nouvelles recherches sur l'ichthyofaune messinienne de Lorca (Murcia, Espagne). Revista española de Paleontología, 10, 175-189 [Corrección, 1996, Ibid., 11, 122-123].

Gaudant, J. 1995b. Nouvelles additions à l'ichthyofaune marine du Messinien de la Sierra de Columbares (Province de Murcia, Espagne). Comptes Rendus de l'Académie des Sciences, Paris, 320 (IIa), 439-446.

Gaudant, J. 2008. L'ichthyofaune messinienne du bassin de Sorbas (Almería, Espagne) et ses rapports avec l'environnement sédimentaire. Revista Española de Paleontología, 23, 211-223.

Gaudant, J. 2014. Fish mass mortality in the Upper Miocene laminated gypsum of western Crete (Hania Province, Greece). Palaeodiversity, 7, 39-45.

Gaudant, J., Courme, M.-D. \& Marín Ferrer, J.M. 2001. Hurchillo (Province d'Alicante, Espagne): un gisement de poissons messiniens d'un type encore inconnu. Comptes Rendus de l'Académie des Sciences, Paris, 333 (IIa), 411-417.

Gaudant, J., Loiseau, J. \& Ott d'Estevou, Ph. 1994. Découverte d'une frayère fossile de poissons téléostéens dans le Messinien des environs de Campos del Río (Province de Murcia, Espagne). Revista Española de Paleontología, 9, 37-50.

Krijgsman, W., Garcés, M., Agustí, J., Raffi, I., Taberner, C. \& Zachariasse, W.J. 2000. The 'Tortonian salinity crisis' of the eastern Betics (Spain). Earth and Planetary Science Letters, 181, 497-511.

Lancis, C., Tent-Manclús, J.E., Soria, J.M., Caracuel, J.E., Corbí, H., Dinarès-Turell, J., Estévez, A. \& Yébenes, A. 2010. Nannoplankton biostratigraphic calibration of the evaporitic events in the Neogene Fortuna Basin (SE Spain). Geobios, 43, 201-217.

Lukowski, P. \& Poisson, A. 1990. Le bassin de Fortuna. In: Les Bassins Néogènes du Domaine bétique oriental (Espagne) (ed. Montenat, C.). Documents et Travaux, Institut géologique Albert de Lapparent, 12/13, 303-311.

Meunier, F.J., Gaudant J. \& Bonelli E., 2010. Morphological and histological study of the hypersostoses of Lepidopus albyi (Sauvage, 1870), a fossil Trichiuridae from the Tortonian (Upper Miocene) of Piedmont (Italy). Cybium, 34, 293-301.

Montenat, C. 1977. Les bassins néogènes du Levant d'Alicante et de Murcia (Cordillères bétiques orientales Espagne). Stratigraphie, paléogéographie et évolution dynamique. Documents du Laboratoire de Géologie de la Faculté des Sciences de Lyon, 69, 1-345.

Müller, D.W. 1986. Die salinitätskrise im Messinian (spätes Miozän) der Becken von Fortuna und Sorbas (SudöstSpanien). Mitteilungen aus dem geologischen Institut der 
Eidg. technischen Hochschule und der Universität Zürich, (N.F.), 257, 1-183.

Müller, D. W. \& Schrader, H. 1989. Diatoms of the Fortuna Basin, southeast Spain: evidence for the intra-Messinian inundation. Paleoceanography, 4, 75-86.

Ryan, W.B.F., Hsü, K.J., Cita, M.B., Dumitrică, P., Lort, J., Maync, W., Nesteroff, W.D., Pautot, G., Stradner, H. \& Wezel, F.C. 1973. Boundary of Sardinia Slope with Balearic Abyssal Plain - sites 133 and 134. Deep Sea Drilling Project, Initial Reports, XIII, 465-514.

Sauvage, H.E. 1875. Notes sur les Poissons fossiles. VI. Sur un poisson des marnes de Lorca (Espagne). Bulletin de la Société géologique de France, (3), 3, 639-641.

Santistebán Bové, C. 1981. Petrología y sedimentología de los materiales del Mioceno superior de la cuenca de Fortuna
(Murcia), a la luz de la crisis de salinidad. PhD Thesis, Universidad Barcelona (unpublished).

Soria, J.M., Tent-Manclús, J.E., Caracuel, J.E., Yébenes, A., Lancis, A. \& Estévez, A. 2005. La crisis de salinidad tortoniense: su registro en la zona de enlace entre las cuencas de Fortuna y del Bajo Segura. Geo-Temas, 8, 113-118.

Tent-Manclús, J.E., Soria, J.M., Estévez, A., Lancis, C., Caracuel, J.E., Dinarès-Turell, J. \& Yébenes, A. 2008. Tortonian Salinity Crisis and tectonics: A view from the Fortuna Basin (SE Spain). Comptes Rendus Geoscience, Paris, 340, 474-481.

Verneuil, E. de \& Collomb, E. 1856. Note sur 1'Espagne. Bulletin de la Société géologique de France, (2), 13, 674-728. 